This is an electronic reprint of the original article. This reprint may differ from the original in pagination and typographic detail.

Author(s): Jäntti, Saara

Title: Children and Childhoods in Women's Madness Narratives

Year: $\quad 2017$

Version:

Please cite the original version:

Jäntti, S. (2017). Children and Childhoods in Women's Madness Narratives. In J. Ahlbeck, P. Lappalainen, K. Launis, \& K. Tuohela (Eds.), Childhood, Literature and Science : Fragile Subjects (pp. 213-224). Routledge. Routledge Advances in Sociology. https://doi.org/10.4324/9781315270784-17

All material supplied via JYX is protected by copyright and other intellectual property rights, and duplication or sale of all or part of any of the repository collections is not permitted, except that material may be duplicated by you for your research use or educational purposes in electronic or print form. You must obtain permission for any other use. Electronic or print copies may not be offered, whether for sale or otherwise to anyone who is not an authorised user. 


\section{Saara Jäntti}

\section{Children and Childhoods in Women's Madness Narratives}

In Sylvia Plath's novel, The Bell Jar, the protagonist, about to go mad, watches a neighbor, heavy with child and busy nurturing another, walk by. This scene signifies her destiny as a woman and her fear of losing herself to the institution and gendered, cultural practices of mothering. For Plath's young protagonist, madness is an escape from motherhood.

Simultaneously, however, the scene also constructs motherhood as a potential future destiny and thus as a source of her impending madness.

This scene from Plath's novel captures the essence of feminist critical discourse of women's madness, where the roots of women's madness lie in the home: in women's social role in childcarrying, child-rearing, domestic work and exclusion from the public sphere. This feminist critical discourse on women's madness (Schlichter 2003), presented in a heterogeneous body of literature, literary criticism and critical psychology, thus forms a feminist etiology of women's madness, and uses the figure of the madwoman to critique social relations and gendered hierarchies. Children, however, are either implicitly or explicitly present in the organization of these relations, and while feminist readings of women's madness narratives tend to adopt the mad narrators' perspective (Kaup 1993, Caminero-Santangelo 1998), this paper focuses on the figurations of children and childhoods in late twentieth-century women's madness narratives to explore, unravel and discuss the kinds of childhoods that are constructed in the texts that take women's madness and its treatment as their subject. As the following reading will show, this literature includes a number of counter-narratives to the literary image of a madwoman represented by Plath's protagonist regarding the role, function and meaning of children, home and nurturing in the lives of psychiatrically diagnosed women who, following their subjection to psychiatric suffering and treatment, have been excluded from the domestic sphere.

Like the figure of the madwoman described above, the child figures in women's madness narratives embody cultural ideals and discourses. 'Figuration' thus refers to the metaphorical use of a concept, here child or childhood, which "ties it to a specific discourse or a set of meanings" 
(Moring 2009, 100). The discourses on children and childhood in women's madness narratives, are intrinsically connected to their contemporary, cultural and psychiatric, understandings of madness and of motherhood, and hence the construction of motherhood is dependent on the ways in which children and childhood are discursively constructed and figuratively employed in these narratives. Here, I discuss four different figurations of children and childhood in madness narratives: the mad women narrators/protagonists as children, the children the protagonists cannot have, and the children that the mad women protagonists have. The examples given thus refer to issues, imagery, discourses and topics that recur in women's madness narratives in the $20^{\text {th }}$ century. These recurring discourses include childhood as a fragile state of becoming, madness as socially and biologically hereditary, and motherhood as both a biological fact, experience and institution (Rich 1974) as well as performative (Jeremiah 2003).

In the psychological literature, children of parents with mental illness have not been widely studied, although, as McConnell et al. (2006, 2542) point out, "mental illness is widely believed to be linked to the ill parent's (mother-child dyad in particular) genetic legacy" and the role of the family context is widely acknowledged even among the proponents of genetic heredity. In this literature on children with mentally ill parents is dominated by the discourse of risk and resilience. In this literature, such children are viewed as being 'at risk' for developing mental illness themselves. Those who do not are considered extraordinarily resilient. McConnell et al. (2006) see this discourse as "rooted within larger discourses about risk and contemporary childhood where childhood is understood as a critical developmental phase. As Qvortrup (1985) suggests, children are seen as 'human becomings' rather than 'human beings' and thus need protection due to their physical and psychological vulnerabilities. (McConnell et al. 2006)

The stories of women's madness discussed in this paper were written during the latter half of the $20^{\text {th }}$ century and thus contemporaneously with the gradual appearance of the Diagnostic and Statistical Manuals I-V, the "Bible of psychiatry," produced by the American Psychiatric Association. The stories thus coincide with the rapid increase in psychiatric diagnoses and (the practice of?) rigorous medicalization psychiatry (Shorter 1997, Porter 2002). By "madness narratives", I refer to stories where the protagonist/narrator has been psychiatrically diagnosed and treated. The term madness, however, refers to the cultural and historical variation and 
change in the understanding of mental suffering and conditions that in the Western world today are regarded as psychopathological (see e.g. Rose 1996). Diagnostic definitions are subject to change and debate, including the medical basis of mental suffering and its treatment (Ussher 2010, Middleton 2015).

In a nutshell, Western psychiatry in the $20^{\text {th }}$ century was characterized by two distinctive discourses, i.e., languages, practices and understandings of the origin and possible modes of cure, respecting psychiatric disturbances: psychoanalytic and bio-medical. Both also have implications for children and childhood: psychoanalytic theories sought the origin of mental disturbance in family dynamics and its cure in a range of talk therapies while biomedicine explored - and suggested - genetic etiologies. Moreover, psychiatric practices such as confinement and seclusion greatly influenced the relations between children and their mad parents and affected the (mothering) practices and possibilities of madwomen (to mother their children). The recent explosion of the psychopharmaceutical industry and treatments has created its own risks. In his History of Psychiatry, Edward Shorter (1997) suggests that psychoanalysis was simply a century-long diversion in an otherwise biologically-based history of psychiatry and psychiatric views and treatments. However, this "diversion" underpins much of the exponential growth in the autopatographical literature on madness (see e.g. Hornstein 2011) that discusses the childhood of the mad protagonist. It is his is the type of childhood that I discuss first - after all, the mad protagonists were once children, too. I then discuss the practices within psychiatry that infantilize the patient, constructing the mad protagonist as children - and thus keeping them from having children. Having discussed the children that the protagonists cannot have, I turn to the children they do have and discuss two different child figures identified in these narratives: the fragile child and the child as a force that pulls the mother out of her madness.

\section{Mad protagonists as children}

In psychoanalytic discourses, childhood and childhood family structures are explored as the primary sources of madness. Corrigan and Miller $(2004,541)$ point out that the "dominant models on the cause of serious mental illnesses during the first half of the 1900s focused on parental weaknesses as causing the early developmental problems of children." Feminist critical discourse, in particular, has called for a challenge to the centuries-old tradition of blaming the 
mother, which, as Jane Ussher claims, "psychology and psychiatry have elevated [...] to the status of scientific fact.” (Ussher 1991, 184). In Lauren Slater's Prozac Diary (1997, henceforth also PD) and Bessie Head's A Question of Power (1974, henceforth also QP), two very different madness narratives, the mad mothers are not really blamed for the madness of the protagonist. Rather, illness becomes a way of identifying with them and the distance brought about by psychiatric suffering and practice.

\section{Childhood remembered}

Lauren Slater, an American psychologist and writer, was one of the first long-term users of Prozac, a tradename for a selective serotonin reuptake inhibitor (SSRI), starting the treatment in the late 1980s. When Slater wrote her book (1998), there were an estimated 12 million users in the United States. In 2001, an estimated 35 million people had used the drug. In Prozac Diary, Slater describes her own conversion from psychoanalytic mother-centered illness identity and narrative to a biomedically based view. Her childhood is marked by her inability to reach her distant and restless mother, described as an undiagnosed madwoman. "Maybe she moved at a pace too fast. Maybe she was too sad. [...]. I think because I couldn't reach her, I couldn't feel myself." $(P D, 16)$ As in Kleinian object relations theory that seems to inform Slater's earlier, psychoanalytic worldview, the mother here is constructed as a primary object with which Slater, as a child, seeks to fill herself. When this fails, Slater is filled with emptiness, and yearns for fulfilment and wholeness. (see also Jäntti 2012, 256). Early on, she discovers that illness is a way to bring her mother closer to her. She learns to love "fevers and flues and the muzzy feeling of a head cold, all these states carrying with them the special accoutrements of illness [...] and best of all, a distant mother coming to your bedside with tea." $(P D, 21)$

For Slater, illness is thus a way to make her mother provide care. Illness and the need and desire for care it involves are intrinsically interlinked. Madness becomes a way of identifying with the mother. Illness is described both as a way to force the mother to perform motherhood and, as a point of identification, for of all the children in the family. Slater describes herself as the one most like her mother. Through illness, Slater and her mother form a symbiotic entity. Thus, for Slater, cure, the departure from illness entails a departure from her mother. Moreover, the fact that the medication works for her, marks a shift from a worldview where human beings are 
understood to be the result of their family histories and childhood dynamics and replacing it by a discourse where genes, tissue, hormones and elements explain who we are and what we become. Understandably, she later describes health as "the hardest departure " $(P D, 83)$

The sick child that Slater remembers herself being is constructed as an inner child, a child within, in a space of entrapment. This child arises in Slater's memories and this remembering is also part of her transition from an illness identity to health. Distancing herself from the sick child is part of her recovery. In a significant scene, Slater, while baking, accidentally spills flour on the floor. This triggers memories of herself compulsively making angels in the snow as a child, and she feels compelled to make a snow angel on the floor. Yet, she is aware that she is not supposed to have such thoughts while on Prozac. She concludes that her sick self is still within her, "hiding behind the branches of my bones [,] peeking out, playful, coy, and pained." $(P D, 97)$.

Significantly, though, Slater points out that what and how the past is remembered also depends on the mood and health of the subject. Part of her medically-induced recovery is based on the way in which her memories of her childhood change according to her health: she describes illness as a state that represses happy memories and health as a state that hides her memories of agony and despair. When ill, she remembers herself as a sick child and writes a poem where ice breaks under a group of skating children. They drown. On medication, she starts to recall skating, making a spin, and her mother clapping her hands $(P D, 192)$. She remembers riding a challenging stallion. On medication, she rediscovers her childhood self as someone with agency and knowhow.

In a very different madness narrative, Bessie Head's A Question of Power set in Southern Africa and Botswana in the early 1970s, Elizabeth, the protagonist, also establishes her own madness as a link to her dead, mad, white mother who died in the mental hospital where she was born. Elizabeth's childhood is deeply affected by her mother's assumed madness and incarceration: She is first taken into foster care, and then to a missionary school where she is repeatedly bullied and placed in isolation due to the stigma of her mother's madness and the headmaster's belief that she has inherited her mother's madness and that this madness could be contagious. Yet, as an adult and after her migration and her own breakdown, Elisabeth redefines her mother's 
madness as "a positive necessity, something which she has inherited and she will carry on as the only heir" (Olaussen 1997, 91).

In A Question of Power, madness is a space where Elizabeth negotiates her past which has repudiated belonging: the origin of her madness and homelessness are rooted in the Apartheid regime, which outlawed inter-racial relationships. As a daughter of a white mother and a black father, Elizabeth, thus is a persona non grata in her "home country" where her origin lies in a criminal act. Elizabeth's family and South Africa both failed to provide her with a holding environment, i.e. an environment bestowing a sense of self and identity. Thus, in Question of Power madness is constructed as a journey and a state of processing inequalities and adverse realities. Unlike in Prozac Diary, where Slater describes her illness as a means of identification and bringing her mother closer, in A Question of Power this identification is only symbolic. Growing up in foster care and boarding schools, Elizabeth is "left with the self-sufficiency of an orphan (QP, 194)” for life. (Jäntti 2012, 161-3).

\section{Infantilization of mental patients}

The (orphan) image (of an orphan) is repeated in Janet Frame's asylum narrative, Faces in the Water, where she describes the conditions of an overcrowded mental asylum in New Zealand in the 1940s and 1950s. But whereas in A Question of Power, Elizabeth's 'is literally an orphan, in Faces in the Water the term is used metaphorically. At a time when cure was rare and periods of seclusion in mental asylums were long, leaving the hospital was a momentous event, and the discourse of "going home" a perennial subject among the inmates. According to Frame, however, when a patient was released, it was better not to talk about it, as "you felt like a child at an orphanage who has been accepted for adoption and must face, when your new parents call for you, the longing gaze of the deprived people around you" (Faces, 54). This figure of a psychiatric patient as an orphan signifies two things: the alienation of the patient from her family environment and her infantilisation inside the psychiatric institution.

Frame's narrative powerfully shows how the patients' infantilization results from the hospitals' practices entwined with the understanding of their illness. The social structure of the two mental hospitals she describes resembles that of a patriarchal family: while the wards are ruled by 
female nurses who treat the patients like children, the absent(-minded) male doctors stand highest in the hierarchy. Decisions regarding patients' clothing, diet and daily rhythms are taken by others, and coercive treatments, such as ECT and insulin treatment, are regularly used as punitive measures for uncooperative behavior (Faces, 28). The infantile position of the patients is emphasized by the fact that the visitors from charity organizations regularly bring them lollipops (Faces, 164-6). Patient infantilization is also reflected in the prohibition on sexual relations in the hospital. As an adult woman, also Istina, the protagonist would have been expected to become a mother. As a mental patient, however, she can only dream of a romance. This distances her from appropriate female corporeality. (Oikkonen 2004) As an institutionalized mental patient, Istina is thus seen as unfitted to the social community outside the hospital, and her body is constructed as uninhabitable for a child (Jäntti 2012, 135).

\section{The children she cannot have}

In the history of women's madness, legalized forced sterilization has been effectively used to prevent women with mental disorders from becoming mothers. In the United States, for example, more than 60,000 mentally retarded or mentally ill individuals, mostly residents of large state institutions, were sterilized for eugenic reasons during the first six decades of the twentieth century. The number of sterilizations continued to rise until the 1930s and then slowly declined. (Reilly 1991). In Faces in the Water, sterilization is not explicitly discussed, but the undesirability of madwomen's reproduction is heavily present in an incident where one of the patients, Hilary, elopes with another patient. When they are caught, she is secluded until it can be certain she is not pregnant.

The legacy of forced sterilization haunts women with mental health problems in the late $20^{\text {th }}$ and early $21^{\text {st }}$ century. In a later book where Lauren Slater (2002) discusses her experience of pregnancy, she claims: "[B]eing a mother and being a mental patient are really mutually exclusive, at least according to law and private opinion as well." (Love Works Like This, henceforth also $L W L T, 11)$ In another memoir, Unquiet Mind, Key Redfield Jamison (1997), a North American psychiatrist and writer with manic-depressive illness, gives an account of her encounter with a doctor: Having been well on medication for an extensive period of time, Jamison conveys to the doctor her desire to, one day, have children. The doctor promptly 
answers: "You shouldn't have children. You have manic-depressive illness." (Unquiet Mind, 191) As a professionally successful and now stable woman, who loves children, Jamison is stunned. She asks the doctor whether he said this because he believed that her illness would make her an inadequate mother or whether he simply thought it unwise to bring another manicdepressive into the world. The doctor replies, "Both." (Unquiet Mind, 191).

The ethical and existential implications of such an answer are tremendous. As Jamison is, herself, a child brought into a world that produced manic-depressive illness, the doctor's answer not only crushes her dreams of having children but also suggests that her own life is not worth living. The implications of the doctor's answer - that life with a mental illness is neither worth living nor worth giving - manifest in different ways in late $20^{\text {th }}$-century women's madness narratives, but always suggest the same thing: madness and motherhood are mutually exclusive. In A Question of Power, Bessie Head, who constructs her protagonist's madness as a journey, also writes: "[j] ourneys of the soul are not for women with children, not all that dark heaving turmoil. They are for men, and the toughest of them took off into the solitude of the forests and fought out their battles with hell in deep seclusion." $(Q P, 50)$. For her, this is because "[t]he inner life is ugly." In today's psychopharmaceutical context, women with mental health problems refrain from having children both due to the ideas of heredity and knowledge - and lack of knowledge - about the possible side-effects of psychopharmaceutical drugs: "Maybe I should get an abortion." Slater writes. (LWLT, 17)

\section{Children of mad mothers}

Madwomen, however, have children and, paradoxically, research shows that women with three or more children are the most vulnerable to developing psychological turmoil and confinement (Ussher 1990, 2010). For women receiving psychiatric treatment, madness and its treatment are factors that prevent or transform their ways of mothering. This is evident in both Faces in the Water and A Question of Power, where hospitalization literally means that mothers are taken and kept away from their children via incarceration.

In Faces in the Water, confinement inevitably affects women's position as mothers. Some, like the patient called Dame Mary Margaret (Ward Two, Cliffhaven), meet their children regularly: 
when her adult son visits her, she wears a special ribbon and returns from the rendezvous with gifts and presents. Most, however, hardly see their children. Madness and confinement thus significantly affect family structures - and the possibility of having one. Madness and psychiatry thus regulate the ability to mother of women who are already mothers and affect patients' possibilities to become mothers. (Jäntti 2012, 130)

\section{Fragile Child}

This legacy also shadows Lauren Slater's decision in the $21^{\text {st }}$ century to have a child. She is aware that both the possible side-effects of the drug and the symptoms of her illness could affect her capacity to mother, and thus need to be considered. However, now that cure is expected outcome of psychiatric conditions, she should first decide whether she is, in fact, mentally ill. She weighs the share of madness in her life: "My first hospitalization occurred when I was fourteen, my last when I was twenty-four. I have devoted exactly one decade to of my life to patienthood. On the one hand, that seems like a lot, given that I have been alive only three decades. On the other hand, that one decade is only one third of my life, and the other two decades are two-thirds of my life, and two-thirds is twice as much as one-third, so I a proportionately healthier, at least time-wise, than I am sicker." ( $L W L T, 11)$ She, however, is skeptical about recovery. For her, "[t]here is never a recovery; there are only remissions." $(L W L T, 17)$

When Slater gets pregnant, she decides to terminate her medication. But the pregnancy itself blurs the boundaries of illness and health for it has aspects that make it hard to distinguish normal from abnormal. Both pregnancy and depression can involve, for example, disturbed sleep and appetite, neurovegetative symptoms and psychomotor retardation. As a psychologist, she knows this well. The difference is hard to tell. $(L W L T, 16)$ In Slater's case, it turns out that there is more to her condition than just pregnancy and she needs to get back on medication. The issue of side-effects becomes even more urgent: Slater's pregnancy, her own health and the health of the baby are all at risk. On medication, she is "wonderfully sane," but her fetal daughter "soaks in the salt of lithium and other pills" (LWLT, 64) 
The fetal child thus becomes an imagined future child, a child at risk and a projection of her mother's fears. According to Donna Haraway (1997), "In many domains in contemporary European and U.S. cultures, the foetus functions as a kind of a metonym, seed crystal, or icon for configurations of person, family, nation, origin, choice, life, and future." Haraway refers to Barbara Duden's (1993) idea of the fetus “as a modern 'sacrum', i.e. "an object in which the transcendent appears", and that functions as a "repository of heterogeneous people's stories, hopes, and imprecations.” (Haraway 1997, 175, cited in Homanen 2013). For Slater's husband (he is a chemist), the child is "an interesting mixture of chemicals." ( $L W L T, 65)$ For Slater, now sane on medication, the questions remain: how to mother when illness recurs? and "Can a mentally ill woman be a good mother?" (LWLT, 17)

The fact that she is on medication enables her to study and contemplate the matter. She resorts to searching the literature for studies on the possible side-effects of the drug. Many are scary, (studies where bunnies have missing eye-lids), but the scariest reports that schizophrenic women were more effective as parents than depressed women. For although "they were crazy as bats, at least they were responsive." (LWLT, 30) To secure their child, careers and Slater's health, Slater and her husband, wealthy as they are, decide to co-parent and hire a live-in nurse to share the nursing of the baby. The practicalities, performatives, of mothering are thus divided between three people. The fragility of the mother and the fragility of the baby are both considered in this arrangement, and, as if to press home her message, Slater presents a scene where her fear for her child's fragility shows in the uncertain way she handles her newborn daughter.

"Don't be so nervous." The nurses assure her.

"She's not going to break, you know."

They laugh at the way I hold her. "Oh, she's not as fragile as she seems," the nurses say." (LWLT, 125)

\section{The child as a force that pulls the mother out of her madness}

In A Question of Power, the protagonist's child, Shorty, is constructed as a force that pulls his mother out of her madness. He is literally depicted as the reason why the racist doctor in the malodorous psychiatric hospital where Elisabeth is taken to sets her free from the hospital. More importantly, however, by requiring nurture and care, Shorty keeps pulling his mother out of her 
nightmare world. Throughout her madness, apart from her two hospitalizations, Elizabeth is to some degree capable of mothering, i.e. providing her child with care and nourishment. It is both Elisabeth's attachment to her son and the necessity of caring for him that motivate Elizabeth's repeated efforts to move from illness towards health, and break out of her hallucinatory nightmares and delusions even when critically ill. (Jäntti 2012, 148) Thus, unlike in much of the early, white feminist work (e.g. Plath 1963/1966, Rich 1991), mothering and children in $A$ Question of Power are constructed as counter-forces to madness and as an empowering, enabling factor in the protagonist's life. This echoes findings in more recent psychiatric studies, showing that for women with severe mental illnesses, children and motherhood have an important role and social function and that the children are a source of personal growth and future hope (Perara et al. 2014). In A Question of Power, there comes a point, however, where Elisabeth is so absorbed in her nightmare world that the protective boundaries between herself and her son blur: she plans to kill them both. But Shorty wakes up and asks her what is happening and why she has been talking to herself. His questions restore her self-awareness and help her to recover her senses slightly. This might seem to suggest that he is taking the role of an adult, but ultimately it is the fact that he assumes his role as a child in need of protection that makes Elisabeth retreat from her destructive plan: "He looked up at her trustingly. For all her haphazard ways and unpredictable temperament, she was the only authority he had in his life. The trust he showed, the way he quietly walked back to his own bed, feverishly swerved her mind away from killing him, then herself." $(Q P, 174)$. Thus, by not allowing his mother to abandon her position as a mother, Shorty restores Elizabeth's sanity. (Jäntti 2012, 209)

Also in A Question of Power, it is the sharing of the performatives of parenting and the practices of other-mothering that safeguard Shorty from his mother's madness. The kindness and benevolence that the villagers, resentful of adult foreigners, show towards Shorty, the fact that they engage with children, and the fact that in the village children can roam freely in and out of others' homes create a safe space in which to grow up. When she is no longer able to take care of him, he finds safety in other homes. Both A Question of Power and Love Works like This suggest that mad mothering is possible and children's wellbeing can be protected when mothering practices are shared rather than individualized. The protagonists' desire and capacity to provide care do not always coincide. Thus, it is necessary to share parenting and establish arrangements 
and structures that acknowledge the vulnerability of the mother as part of her parenting. The fact that previous studies in feminist psychology show that motherhood may render women vulnerable to mental disturbances calls us to reassess the practices and demands of mothering more broadly. The stories (discussed here?) suggest that shared parenting, whether in a village community or nuclear family is protective of health for both children and their mothers.

\section{Conclusions}

The construction of childhood in these novels on women's madness are dependent on the psychiatric context, psychiatric culture in which the madness is experienced and the narrative is written, and on the practices of mothering prevalent in the culture in question. Thus, madness and insanity may still exclude motherhood when diagnosed in women who are not mothers, and it clearly transforms the motherhood of those who are already mothers when diagnosed. (Jäntti 2012, 130)

The figurations of children and childhoods in the late $20^{\text {th }}$-century narratives by psychiatrically treated women discussed here include the protagonist as a child - and as a child of a mad mother. While madness may not be inherited, it can provide a source of identification for a child or, as in Slater's case, a means of creating rapport with a distant parent. The adult protagonist's former, sick self is constructed as an inner child. However, some psychiatric practices infantilize adult women. While forced sterilization is no longer widely practiced in the Western countries, along with social sanctions, lack of cures and support, it continues to cause women with psychiatric diagnoses to refrain from having children. However, the mad mothers stories underline their need to protect their born and unborn children against the (side-)effects of both madness and its treatment. Children can also function as a force that pulls their mothers out of madness, enable and enhance recovery, but are also at risk due to their mothers' mental state . Children can also be protected by shared parenting practices, while with pharmacotherapy, the fetal child remains a "scientific experiment."

\section{Bibliography}


Bhana, Hersini (2004) Reading Ghostly Desire: Writing the Edges of Bessie Head's A Question of Power. In Ibrahim, Huma (ed.). Emerging Perspectives on Bessie Head. Trenton, Eritrea: Africa World Press.

Caminero-Santangelo, Marta (1998) The Madwoman Can't Speak. Or Why Insanity Is Not Subversive. Ithaka, London: Cornell University Press.

Corrigan, Patrick W. \& Frederick E. Miller (2004) Shame, blame, and contamination: A review of the impact of mental illness stigma on family members. Journal of Mental Health, 13(6), 537 -548 .

Diaz-Caneja, A., \& Johnson, S. (2004) The views and experiences of severely mentally ill mothers: a qualitative study. Social Psychiatry and Psychiatric Epidemiology, 39(6), 472-482.

Retrieved from http://dx.doi.org/10.1007/s00127-004-0772-2.

Duden, Barbara (1993) Disembodying women. Perspectives on pregnancy and the unborn. Cambridge: Harvard University Press.

Frame, Janet (1961/1980) Faces in the Water. London: Women's Press.

Head, Bessie (1974) A Question of Power. London: Heinemann.

Homanen, Riikka (2013) Doing Pregnancy, the Unborn, and the Maternity Healthcare Institution. PhD Thesis. Tampere University Press.

Hornstein, Gail (2011) Bibliography of First-Person Narratives of Madness in English (5th edition). http://www.gailhornstein.com/works.htm (Accessed 15-8-2016). Jamison, Kay Redfield (1995/1997) An Unquiet Mind. Memoirs of Moods and Madness. Basingstoke and Oxford: Picador.

Jeremiah, Emily (2003) Troubling Maternity: Mothering, Agency, and Ethics in Women's Writing in German of the 1970s and 1980s. Leeds: Maney/MHRA

Jäntti, Saara (2012) Bringing Madness Home. The Multiple Meanings of Home in Janet Frame's Faces in the Water, Bessie Head's A question of Power and Lauren Slater's Prozac diary. PhD Thesis. University of Jyväskylä: Studies in Humanities. Available from: https://jyx.jyu.fi/dspace/handle/123456789/37880. [Accessed 25th November 2016]. Kaup, Monica (1993) Mad Intertextuality: Madness in Twentieth-Century Women's Writing. Trier: Wissenschaftlicher Verlag Trier.

Margree, Victoria (2004) Wild Flowers: Bessie Head on Life, Health and Botany. Paragraph. 27 (3). p.16-31. Available from: http://web.a.ebscohost.com/. [Accessed 25th November 2015]. 
McConnell Gladstone, Brenda, Katherine M. Boydella, and McKeever, Patricia (2006) Recasting research into children's experiences of parental mental illness: Beyond risk and resilience. Social Science \& Medicine 62, 2540-2550. doi:10.1016/j.socscimed.2005.10.038

Middleton, Hugh (2015) Psychiatry Reconsidered. From Medical Treatment to Supportive Understanding. Palgrave Macmillan

Moring, Anna (2009) Domestication into heteronormativity: Figurations of the Queer-inhabited home in Finnish magazines and papers between 2002 and 2005 in Homes in Transformation. Dwelling, Moving, Belonging. (2009) Johansson, Hanna and Kirsi Saarikangas (eds.) Helsinki: SKS, pp. 100-122.

Oikkonen, Venla (2004) “Mad Embodiments: Female Corporeality and Insanity in Janet Frame's Faces in the Water and Sylvia Plath's The Bell Jar." The Electronic Journal of the Department of English 3. The University of Helsinki.

Olaussen, Maria (1997) Forceful Creation in Harsh Terrain. Place and Identity in Three Novels by Bessie Head. Frankfurt am Main: Peter Lang.

Perera, Dinali N., Short, Liz and Fernbacher, Sabin (2014) There is a lot to it: Being a mother and living with a mental illness. Advances in Mental Health 12(3): 167-181.

Plath, Sylvia (1963/1966) The Bell Jar. London: Faber and Faber.

Qvortrup, J. (1985). Placing children in the division of labour. In R. Close, \& R. Collins (Eds.), Family and economy in modern society. London: Macmillan.

Reilly, Philip R. (1991) The Surgical Solution: A history of involuntary sterilization in the united States. Baltimore: Johns Hopkins University Press.

Rich, Adrienne (1974/1991) Of Woman Born: Motherhood as Experience and Institution. London: Virago.

Rose, Jacqueline (1996) On the 'Universality' of Madness: Bessie Head's A Question of Power. In States of Fantasy. Oxford: Clarendon Press.

Schlichter, Annette (2003) "Critical Madness, Enunciative Excess: The Figure of the Madwoman in Postmodern Feminist Texts.” Cultural Studies - Critical Methodologies, 3 (3), 308-329. Shorter, Edward (1997) A History of Psychiatry. From the Era of the Asylum to the Age of Prozac. New York: John Wiley \& Sons.

Showalter, Elaine (1987) The Female Malady. Women, Madness and the English Culture 1830-1980. London: Virago. 
Slater, Lauren (1999) Prozac Diary. New York: Penguin Books.

Slater, Lauren (2002) Love Works like This. Travels Through A Pregnant Year.

Ussher, Jane (2010) Are We Medicalizing Women's Misery? A Critical Review of Women's

Higher Rates of Reported Depression. Feminism \& Psychology. 20 (1). p.9-35. Available from: http://fap.sagepub.com/. [Accessed 25 November 2015.] 